\title{
BIOFORTIFICATION OF MAIZE FLOUR WITH GRAIN AMARANTH FOR
} IMPROVED NUTRITION

\section{Kamotho $\mathrm{SN}^{1 *}$, Kyallo $\mathrm{FM}^{1}$ and DN Sila ${ }^{1}$}

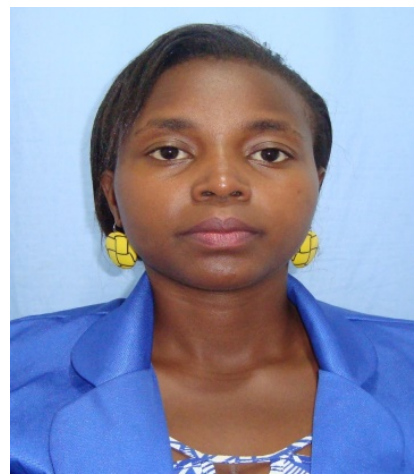

Sylviah Kamotho

*Corresponding author: sylviah kamotho@yahoo.com

${ }^{1}$ Department of Food Science and Technology, Jomo Kenyatta University of Agriculture and Technology P.O. Box 62000-00200, Nairobi, Kenya 


\section{ABSTRACT}

Food insecurity and malnutrition remain two major problems in Kenya that cause undernutrition (protein-energy malnutrition) and nutrient deficiencies. In a bid to combat the problem, the government has targeted increased production of the micronutrient (minerals, vitamins) fortified maize flour. This is mostly based on chemical fortificants, which is a short-term measure that targets reducing the level of malnutrition while creating better livelihoods. However, there is need to think about long- term and sustainable strategies. Among the causes that have led to food and nutrition insecurity in the country is the over reliance on maize as the staple food. Other staples in Kenya are sorghum, rice and millet. This study aimed at providing a better and more sustainable approach by fortifying maize based diets with grain amaranth. Maize was procured from National Cereals and Produce Board and processed to refined flour, while amaranth grain that had been toasted at $100^{\circ} \mathrm{C}$ for 5 minutes and milled into flour was obtained from Annicos Limited Company, Nairobi. Complementary formulations were then prepared by blending the flours. The refined maize flour was mixed with varying ratios of 0,20 , 30 and $40 \%$ of the grain amaranth flour. The proximate composition, mineral content and microbiological analysis of the raw materials and the blends were determined using recognized standard methods, while protein digestibility was determined after enzyme digestion. Nutritional composition of grain amaranth flour differed significantly $(p \leq 0.05)$ as compared to refined maize flour; amaranth flour was found to be superior in proteins $(15.82 \%)$, lipids $(7.61 \%)$, ash $(2.54 \%)$ and fibre $(4.39 \%)$, as compared to proteins $(6.29 \%)$, lipids $(1.92 \%)$, ash $(0.55 \%)$ and fibre $(0.76 \%)$ in refined maize flour. Adding grain amaranth flour to refined maize flour at the different ratios increased the nutrient density significantly $(\mathrm{p} \leq 0.05)$, particularly protein, iron, calcium and zinc. However, it decreased the digestibility of protein significantly $(\mathrm{p} \leq 0.05)$. The results indicate that although adding $40 \%$ grain amaranth gave the best results, the most acceptable blend was the $20 \%$ grain amaranth addition. They also indicate that "food to food" fortification can be an approach that can be adapted towards meeting the nutrition requirements of the society.

Key words: Nutrition security, biofortification, amaranth flour, maize flour, optimal blend 


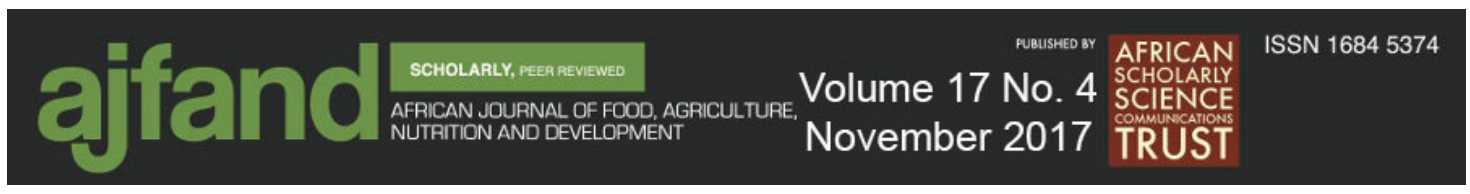

\section{INTRODUCTION}

Amaranth is an annual herb and is a pseudo cereal native to South and Central America [1]. There are about 60 amaranth species and between $4000-6000$ varieties [2]. These species are cultivated in the world as cereals, leafy vegetables, or ornamental plants, while others occur naturally as weeds. Grain amaranth is mainly characterized by large flower heads which produce thousands of dicot seeds. It thrives mostly in temperate and tropical regions and also in poor soils and arid conditions [3]. In Kenya, the crop is mainly grown in Central, Western and Nyanza regions naturally in open fields in the rural areas. The average yield in fields is highly dependent on the weather patterns and agronomic practices [1]. This means that a lot of arid and semi-arid areas can be converted to amaranth producing zones without compromising maize production. Amaranth grain contains significantly higher protein than most other cereal grains. In particular, it has a relatively high proportion of lysine, an essential amino acid limited in maize, leading to its effective utilization as a protein source [4]. It is also a good source of fats [5], carbohydrates, fibre, sugars, vitamins (A, B, C, E) and minerals (iron, calcium and zinc) [6].

Malnutrition is a widespread problem in Kenya, mainly manifested through undernutrition (protein-energy malnutrition) and micronutrient deficiency. On a national level, $35 \%$ of children under 5 years are stunted, $16 \%$ are underweight and $7 \%$ are wasted [7]. Prevalence of under-nutrition is high in urban slums where stunting among children under 5 years is more than $40 \%$ [8]. Food and nutrition insecurity, aggravated by the over reliance on staple foods, especially highly refined maize, is the main cause of undernutrition in Kenya. Besides children, the other most vulnerable individuals are pregnant and lactating mothers, the elderly and refugees [9].

Maize is a staple food in many African countries and thus provides opportunities for nutritional interventions and could be the main vehicle in fortification programs. Currently, maize flour is being fortified with vitamins $A, B_{1}, B_{2}, B_{6}$, niacin and folate; iron and zinc. However, concerns on bioavailability, lipid oxidation and sensory quality resulting from fortification have previously been raised [10]. In Kenya, it is now government policy to fortify all flours. This is geared towards mitigating malnutrition within the vulnerable groups. The use of chemical fortificants is a short-term measure which targets reducing the level of malnutrition while creating better livelihoods. However, there is need for long-term and sustainable strategies. In this project, other than using chemical fortificants, a food diversification approach is applied in which maize flour is fortified using grain amaranth. This approach has been previously recommended for unfermented porridge where it was shown that inclusion of $70 \%$ amaranth flour in porridge would increase dietary iron intake among children in Kenya [11]. It is anticipated that this will be more sustainable since amaranth is locally available and the nutritional outcomes are better. 


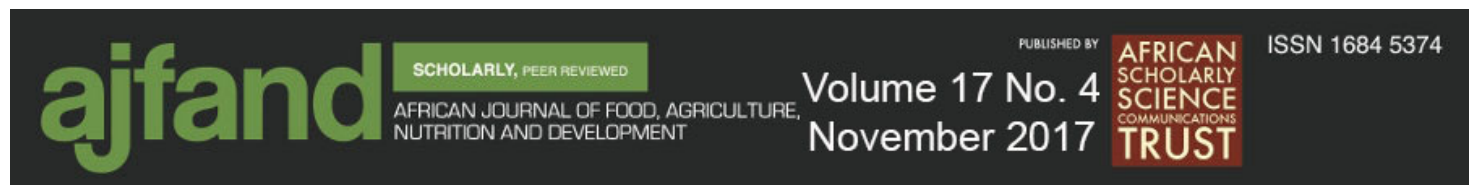

\section{MATERIALS AND METHODS}

\section{Sample preparation}

Maize grain was provided by the National Cereals and Produce Board and processed to refined flour, while amaranth grain which had been toasted at $100^{\circ} \mathrm{C}$ for 5 minutes and milled into flour was obtained from Annicos Limited, Nairobi. The refined maize flour was mixed with inclusions of $0 \%$ refined maize flour (RMF), 20\% (RA1), 30\% (RA2) and $40 \%$ (RA3) of the grain amaranth flour as shown in Table 1. Preliminary studies indicated that with above $40 \%$ of grain amaranth, the product loses its cooking-pasting properties. Complementary meals were then prepared from the refined maize flour and the different blends of the flours.

\section{Determination of proximate composition}

Proximate composition of the raw materials and blends were determined as follows: Moisture content was determined by the oven-drying method according to AOAC [12] method 930.04; Crude protein ( $\mathrm{N}$ x 6.25) was determined using semi-micro Kjeldahl method according to the AOAC procedure 978.04[12]; Crude fat was determined by the Soxhlet extraction according to the AOAC method 920.85[12]; Crude ash was determined by ashing according to AOAC method 923.05[12]; Crude fibre was determined by the Hennenberg-Stohman according to AOAC method 920.86[12]. A 5 gram sample was used for each replicate. Total carbohydrates content of the samples was determined by difference [13]. Nutritional analysis was carried out in triplicate for the raw materials (refined maize flour (RMF) and grain amaranth flour (GAF)) and the different blends (RA1, RA2, RA3).

\section{Determinations of mineral composition}

The ash that was previously determined was cooled and dissolved in $15 \mathrm{ml} \mathrm{10 \%} \mathrm{HCl}$ in a volumetric flask, which was then topped up to $100 \mathrm{ml}$ mark with distilled water. This was used for mineral determination according to the AOAC method [13]. Iron, calcium and zinc were determined by Atomic Absorption Flame Spectrophotometer (Model A. A-6200, Shimadzu, Kyoto, Japan).

\section{Determination of Protein Digestibility}

Protein digestibility was determined according to the method by Hamaker et al. [14], whereby $1 \mathrm{~g}$ samples were digested in $2 \mathrm{ml}$ of pepsin for 2 hours at $37^{\circ} \mathrm{C}$. The residual protein was then determined using semi-micro Kjeldahl method according to the AOAC procedure 978.04 [12].

\section{Microbiological analysis}

Microbial analysis was done for samples kept for 0,3 and 6 months. Total plate counts were determined on Plate Count Agar pour plates and enumerated after an incubation period of $48-72$ hours at $37^{\circ} \mathrm{C}$. Escherichia coli were enumerated on Violet Red Blue Agar pour plates after an incubation period of 24 hours at $37^{\circ} \mathrm{C}$. Yeast and moulds were enumerated on Potato Dextrose Agar pour plates after an incubation period of 120 hours at $25^{\circ} \mathrm{C}[15]$. 


\section{Sensory analysis}

Thirty semi-trained panellists consisting of staff members and graduate students from Jomo Kenyatta University of Agriculture and Technology evaluated 'ugali' made from the different blends. All samples were prepared and cooked in clean drinking water boiled for 10 minutes and the flour blends added and mixed to make 'ugali'. Characteristics evaluated were: a) Appearance, b) Colour, c) Mouth feel, d) Texture, e) Taste and f) Overall preference. A 9-point hedonic scale [16] was used to measure the consumer acceptability of the products. The relative importance of each factor was compared numerically on a scale of 9 to 1 ( $9=$ like extremely, $1=$ dislike extremely). Each panellist gave a score. The average score for each sample was then calculated.

\section{Data analysis}

Each determination was carried out in triplicate, the figures were averaged and standard error calculated. Data were subjected to ANOVA $(\mathrm{p} \leq 0.05)$ using GenStat $14^{\text {th }}$ edition (VSN international, UK). Comparison of treatment means was done using Duncan's Multiple Range Tests [17].

\section{RESULTS}

The nutritional composition of the raw materials and the formulated blends are shown in Table 2. There were significant differences $(p \leq 0.05)$ in the moisture content of the flours. The moisture content of grain amaranth flour (GAF) was found to be lower than that of the refined maize flour (RMF), and all the maize-amaranth flour blends (RA1, RA2 and RA3). The moisture content of the flour blends was within the range of $11.11-12.57 \%$.

Grain Amaranth Flour (GAF) had significantly $(\mathrm{p} \leq 0.05)$ higher lipid content than refined maize flour $(R M F)$. Significant differences $(p \leq 0.05)$ in lipid content were observed among the blends. The lipid content of the blends ranged from $3.75-4.63 \%$ with RA3 being the highest. Similarly, GAF had significantly $(p \leq 0.05)$ higher protein content than RMF. Significant differences $(\mathrm{p} \leq 0.05)$ in protein content were observed among the blends. The protein content of the blends ranged from $6.62-8.80 \%$ with RA3 being the highest. Crude fibre was significantly $(\mathrm{p} \leq 0.05)$ higher in GAF as compared to RMF. Significant differences $(\mathrm{p} \leq 0.05)$ were observed among the blends. The fibre content of the blends ranged from $0.83-2.99 \%$ with RA3 being the highest. Grain Amaranth Flour had significantly $(p \leq 0.05)$ higher ash content than RMF. Significant differences $(p \leq 0.05)$ were observed among the blends. The ash content of the blends ranged from 0.83 $1.10 \%$. Sample RA3 had the highest nutritional composition. Refined maize flour had significantly $(\mathrm{p} \leq 0.05)$ higher carbohydrate content than GAF. Significant differences $(p \leq 0.05)$ were observed in the carbohydrate content of the blended flours. The carbohydrate content of the blended flours ranged from $71.38-77.44 \%$.

The mineral composition of the raw materials and the formulated blends are shown in Table 3. The results indicate that there was a significant difference $(\mathrm{p} \leq 0.05)$ between GAF and RMF. GAF was higher in calcium, iron and zinc as compared to RMF. Significant differences $(\mathrm{p} \leq 0.05)$ were also observed in the mineral content of the blended flours. Sample RA3 had the highest levels of the minerals analysed namely, calcium, iron and zinc. 


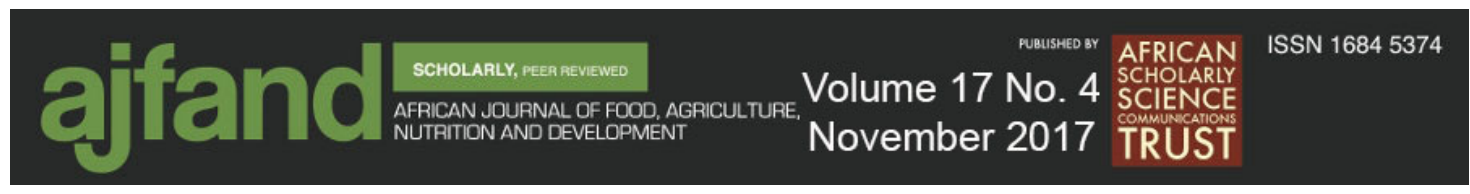

Figure 1 shows that the protein digestibility of the different flours and blends ranged from $77.04-86.24 \%$. Refined maize flour had significantly $(\mathrm{p} \leq 0.05)$ higher protein digestibility than GAF. There were significant differences $(\mathrm{p} \leq 0.05)$ observed among the blends with RA1 being the highest.

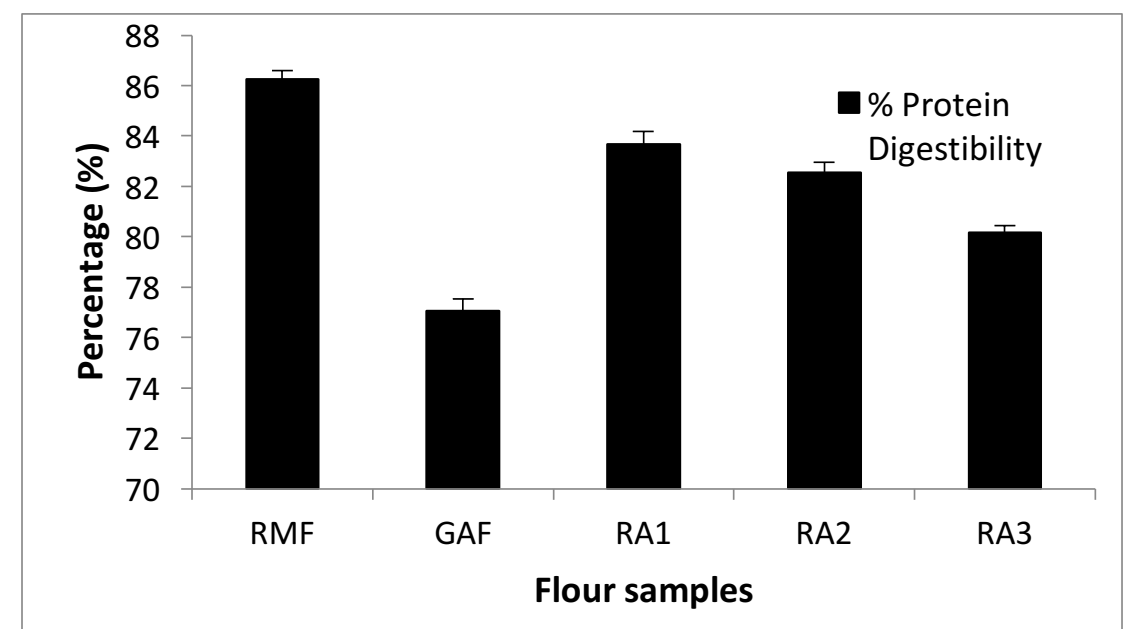

Figure 1: Protein digestibility of the different flour samples. RMF- Refined Maize flour, GAF- Grain Amaranth flour, RA1- 80:20 (RMF:GAF) RA2- 70:30 (RMF:GAF), RA3- 60:40 (RMF:GAF)

The results in Figure 2 indicate the microbial counts during storage. Grain Amaranth Flour (GAF) had significant ( $\mathrm{p} \leq 0.05)$ lower microbial counts (Total plate count (A), $E$. coli (B) and yeasts and moulds (C)) as compared to RMF during the storage interval. Significant differences $(\mathrm{p} \leq 0.05)$ were also observed among the blends. All samples followed an increasing trend as the storage months progressed.

The sensory attributes of 'ugali' made from the different blends are shown in Table 4. Generally, the different variations of "ugali" samples were either acceptable or neutral with significant differences $(p \leq 0.05)$ among the products. However, there was no significant difference $(\mathrm{p} \leq 0.05)$ in all the sensory attributes between RA2 and RA3. The colour of the 'ugali' prepared from RMF was most preferred followed by RA1 and RA2. The mouth feel, texture and taste from RMF were most preferred. The results show that the most acceptable blend was RA1. 

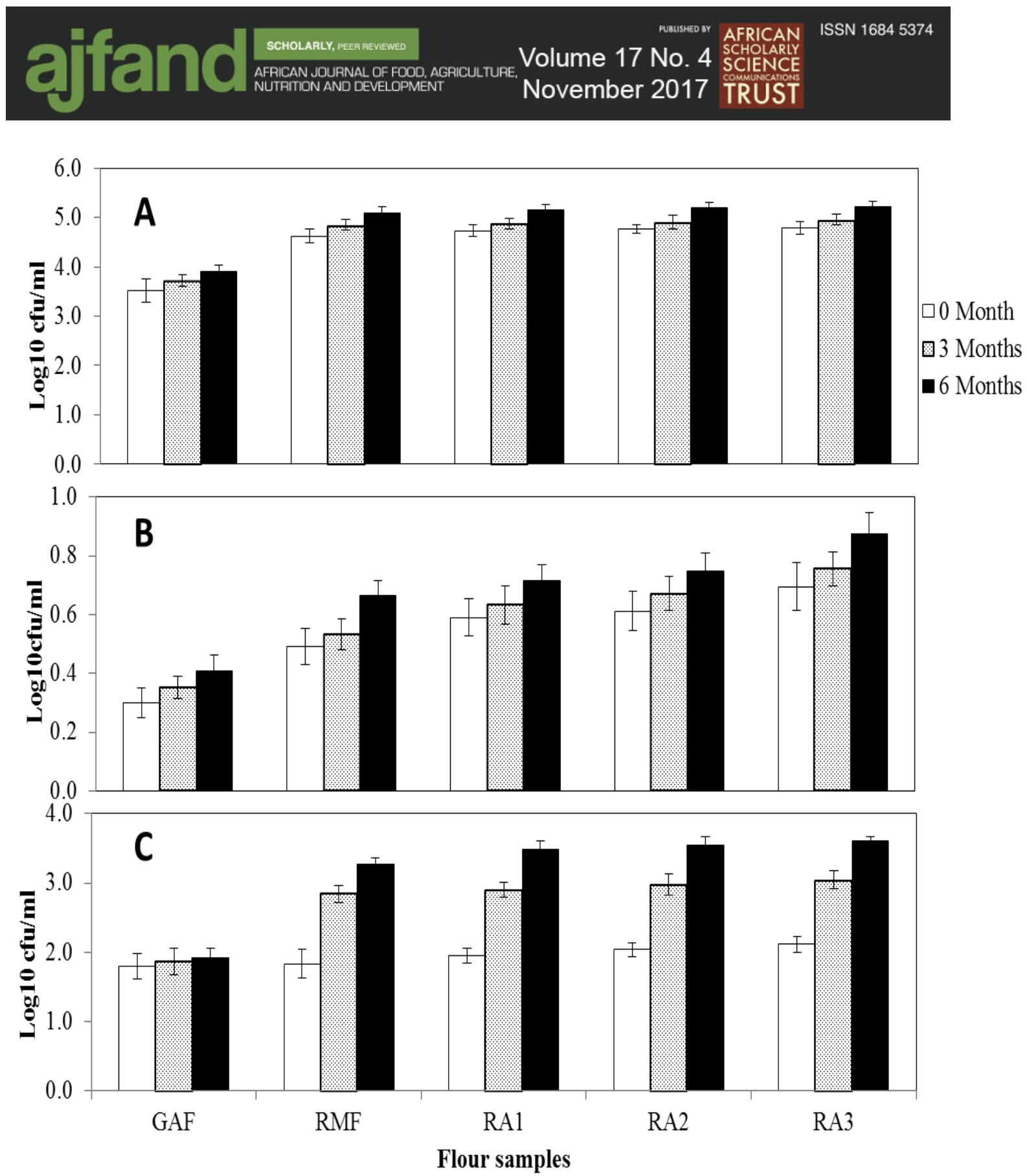

Figure 2: Total plate count (A), E. Coli (B), and fungal (yeasts and moulds) count (C) of the different flour samples. GAF- Grain Amaranth flour, RMFRefined Maize flour, RA1- 80:20 (RMF: GAF), RA2- 70:30 (RMF:GAF), RA3- 60:40 (RMF:GAF)

\section{DISCUSSION}

The moisture content of grain amaranth flour (GAF) was lower than refined maize flour (RMF) and all the maize-amaranth flour blends (RA1, RA2 and RA3). The moisture content of all the flours was within the recommended limit of 15.5\% [18]. The low moisture contents observed in this study is an indicator of longer shelf life of the 
products. Moisture content is highly dependent on the duration of the drying process, thus an index of storage stability of the flour.

Increase in the proportion of GAF in the blends resulted in increase of protein, lipid, fibre and ash content. The protein content of GAF was similar to previously reported values [6]. Therefore, the use of grain amaranth flour in blending RMF increases the biological value of the blends [19]. Increasing the refinement degree of maize flour eliminates much of the germ portion. This results in removal of most of the oil which is found mainly in the germ. Ash content is an indication of the total mineral matter in the flour. All the samples were within the acceptable range of up to $3 \%$ ash [18]. Generally, removal of the outer skin of the maize during the milling process reduces the ash, protein and fat content [20]. The high carbohydrate content $(61.19-77.75 \%)$ observed in this study indicates that the samples are energy dense foods which can be incorporated in addressing energy malnutrition.

From the studies, sample RA3 had the highest amounts of the minerals analysed. This indicates that grain amaranth can successfully be used to improve the micronutrient content of refined maize flour. Calcium plays a key role in bone and tooth development, nerve transmission and muscular contractions. Iron is a haemoglobin component which transports oxygen to body tissues. It is also a component of proteins and enzymes. Iron deficiency especially in infants, has been associated with cognitive impairment and mental development [21]. Zinc is an essential component of most enzymes in the body [22]. The increased popularity and use of highly milled maize meal as opposed to traditionally ground or lightly milled maize results in deficiency of such micronutrients. The mineral constituents lost in milling may be replaced in maize meal, as in other cereal flours, by fortification with grain amaranth flour as indicated by the results.

The protein digestibility of RMF was higher than that reported of $84.5 \%$ [23]. Higher protein digestibility in refined maize flour was probably due to the reduction of the antinutrients level during milling [24]. Reported values on protein digestibility of grain amaranth range between $74-80 \%$ [7]. In vitro digestibility of $61-76 \%$ has previously been reported for raw grain amaranth proteins [25]. The in vitro protein digestibility of grain amaranth in this study were higher than reported values for whole raw maize $(66.6 \%)$ and sorghum $(55.8-59.1 \%)[26]$.

The relatively low protein digestibility of the GAF as compared to RMF in this study may be attributed to the influence of anti-nutrients such as phytates, tannins, enzyme inhibitors, lectins and dietary fibre. These anti-nutrients interact with protein to form complexes that decrease protein solubility [24]. Increase of GAF in the blend resulted to reduced protein digestibility. The decrease could be attributed to the high content of antinutrients in grain amaranth flour. Low protein digestibility in the diet affects the bioavailability of the amino acids and also the protein quality of the food. However, the higher protein content of GAF will compensate for the reduced digestibility in the blends.

Generally, flour is considered a microbiologically safe product due to its low water content [27]. The results in Figure 2 indicate the rate of microbial growth during storage intervals. Grain Amaranth Flour had significantly $(\mathrm{p} \leq 0.05)$ lower microbial counts as 
compared to RMF. This may be due to the fact that the grains were toasted for 5 minutes at $100^{\circ} \mathrm{C}$ before milling, therefore, reducing the microbial load. Studies have shown few cases on foodborne disease outbreaks caused by flours [28]. High microbial counts found in refined maize flour may be attributed to microbes already present in the cereal before milling, and/or the milling method. Build-up of residues at the storage and handling points may be a source of contamination [28]. Increase in microbial load of the blends during storage could be attributed to the blends having a better nutrient base than refined maize meal. Therefore, the blends offered better growth conditions for microbes.

The level of contamination of fungi (yeasts and moulds) is highly important as it affects the quality and safety of the flour. The maximum legal limit for fungi in flour is $\log _{10} 5$ $\mathrm{cfu} / \mathrm{g}$ [18]. Yeasts and moulds from the results were within the recommended limits. Yeast and moulds in the blends increased with increased storage time. This could be as a result of favourable conditions of the microbes to grow. Fungi levels beyond the maximum limit lead to deterioration of foods and cause foodborne diseases. Moulds may produce enzymes which begin to degrade the lipids, consequently affecting the quality parameters of the maize meal during storage. Bothast et al. [29] found that both bacteria and mould counts in maize meal increased during the storage period before finally decreasing.

Escherichia coli and total plate count (TPC) indicate the hygienic properties and gives information on shelf life of the food. Higher counts beyond the maximum limit indicate poor sanitation in the processing methods as well as mishandling of the raw products. Escherichia coli were detected in all the samples at fairly low levels and the results were within the World Food Program (WFP) maximum limits of $\log _{10} 1 \mathrm{cfu} / \mathrm{ml}$. The maximum legal limit for total plate count is $\log _{10} 5 \mathrm{cfu} / \mathrm{ml}$ [18]. The results obtained were, therefore, consistent with WFP recommendations [18] up to 3 months. However, the shelf life of the blends could be improved by applying Good Agricultural Practices (GAP).

Incorporation of grain amaranth flour to refined maize flour significantly $(p \leq 0.05)$ reduced the attributes of appearance, colour, mouth feel, texture, taste and overall acceptability. However, there was no significant difference $(\mathrm{p} \leq 0.05)$ in all the sensory attributes between RA2 and RA3.The colour of the 'ugali' prepared from RMF was most preferred followed by RA1 and RA2. The preference for RMF could be due to its lightest colour. Increase of grain amaranth flour resulted in darker colouration. The mouth feel, texture and taste from RMF were most preferred. Addition of grain amaranth flour resulted in the product obtaining a 'grainy' texture. The results show that the acceptable blend was RA1. Further increase of the grain amaranth flour in the blends resulted in progressive decline in acceptability. This can be explained by familiarity of solely maize flour.

\section{CONCLUSION}

From the study, grain amaranth flour is highly nutritious particularly with respect to proteins, fat and minerals, as compared to refined maize flour. Blending refined maize flour with grain amaranth flour significantly increases the nutritional quality of the refined maize flour. The sample with the highest nutritional profile was the blend with 


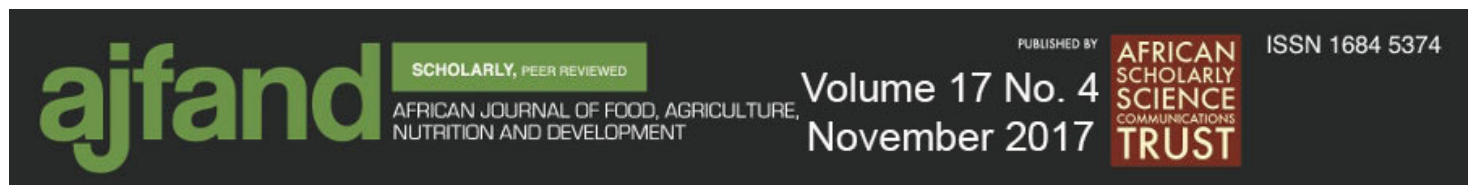

$40 \%$ grain amaranth flour, while the most acceptable blend was the $20 \%$ grain amaranth addition. The approach of food- food fortification can provide a sustainable alternative to current chemical fortification approaches if indigenous food crops of high nutrient content are incorporated into common staple diets. Grain amaranth can successfully be used in mitigating nutrition insecurity and reducing malnutrition levels in Kenya if used in blended maize recipes.

\section{ACKNOWLEDGEMENT}

I wish to express my sincere gratitude and appreciation to the Australian Government (AusAID) through, BecA hub-CSIRO initiative on Food and Nutrition Security for sponsoring and enabling the completion of this research work at Jomo Kenyatta University of Agriculture and Technology. 


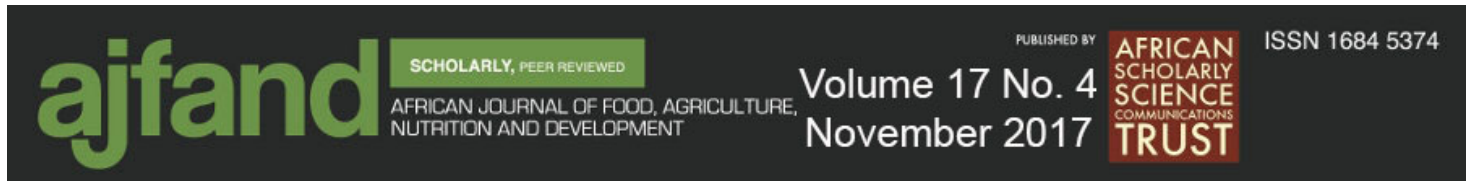

Table 1: Formulation of maize and amaranth blends

\begin{tabular}{llllll}
\hline & RMF & RA1 & RA2 & RA3 & GAF \\
\hline Refined Maize Flour & 100 & 80 & 70 & 60 & 0 \\
Grain Amaranth Flour & 0 & 20 & 30 & 40 & 100 \\
Total Weight (g) & 100 & 100 & 100 & 100 & 100 \\
\hline
\end{tabular}

RMF- Refined Maize flour, GAF- Grain Amaranth flour, RA1- 80:20 (RMF: GAF) RA2-70:30 (RMF: GAF), RA3- 60:40 (RMF: GAF)

Table 2: Proximate composition of the raw materials and the blends

\begin{tabular}{lllllll}
\hline Samples & Moisture & Crude & Crude & Crude & Crude & CHO \\
& & fat & Protein & Ash & Fibre & \\
\hline RMF & $12.73^{\mathrm{d}} \pm 0.0$ & $1.92^{\mathrm{a}} \pm 0.27$ & $6.29^{\mathrm{a}} \pm 0.17$ & $0.55^{\mathrm{a}} \pm 0.05$ & $0.76^{\mathrm{a}} \pm 0.10$ & $77.75^{\mathrm{c}} \pm 0.26$ \\
& 9 & & & & & \\
GAF & $8.34^{\mathrm{a}} \pm 0.02$ & $7.61^{\mathrm{d}} \pm 0.21$ & $15.82^{\mathrm{e}}$ & $2.54^{\mathrm{d}} \pm 0.02$ & $4.50^{\mathrm{d}} \pm 0.13$ & $61.19^{\mathrm{a}} \pm 0.57$ \\
& & & \pm 0.22 & & & \\
RA1 & $12.57^{\mathrm{d}} \pm$ & $3.75^{\mathrm{b}} \pm 0.19$ & $6.62^{\mathrm{b}} \pm 0.22$ & $0.83^{\mathrm{b}} \pm 0.01$ & $1.78^{\mathrm{b}} \pm 0.19$ & $77.44^{\mathrm{d}} \pm 0.51$ \\
& 0.02 & & & & & \\
RA2 & $12.15^{\mathrm{c}} \pm$ & $4.11^{\mathrm{bc}} \pm$ & $7.92^{\mathrm{c}} \pm 0.24$ & $1.04^{\mathrm{c}} \pm 0.01$ & $2.15^{\mathrm{b}} \pm 0.26$ & $72.63^{\mathrm{c}} \pm 0.24$ \\
RA3 & 0.03 & 0.08 & & & & \\
LSD 5\% & 0.377 & 0.585 & 0.141 & 0.121 & 0.7077 & 1.179 \\
Grand & 11.38 & 4.41 & 9.09 & 1.21 & 2.433 & $71.48^{\mathrm{b}} \pm$ \\
Mean & 0.11 & $4.63^{\mathrm{c}} \pm 0.13$ & $8.80^{\mathrm{d}} \pm 0.12$ & $1.10^{\mathrm{c}} \pm 0.03$ & $2.99^{\mathrm{c}} \pm 0.18$ & $71.38^{\mathrm{b}} \pm 0.22$ \\
\hline
\end{tabular}

Means within the same column with different alphabetic superscripts were significantly different at $(\mathrm{p} \leq 0.05)$, values are presented as means \pm standard error, $\mathrm{n}=3$

CHO - Carbohydrates, LSD - Least Significant Difference 


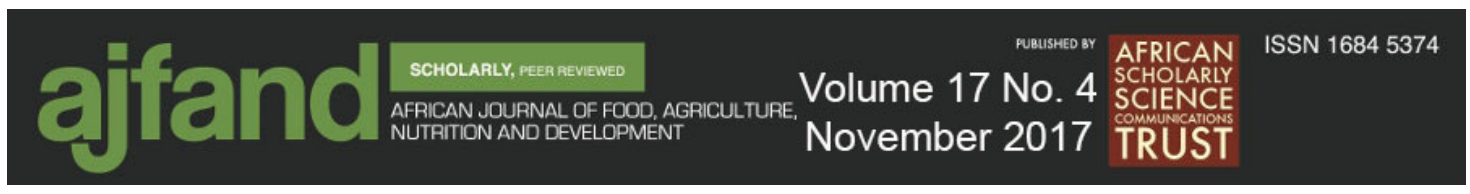

Table 3: Mineral composition of raw materials and the blends

\begin{tabular}{llll}
\hline Samples & Calcium & Iron & Zinc \\
\hline RMF & $2.46^{\mathrm{a}} \pm 0.15$ & $0.72^{\mathrm{a}} \pm 0.08$ & $0.67^{\mathrm{a}} \pm 0.02$ \\
GAF & $290.13^{\mathrm{e}} \pm 1.30$ & $9.58^{\mathrm{e}} \pm 0.14$ & $4.38^{\mathrm{e}} \pm 0.03$ \\
RA1 & $57.1^{\mathrm{b}} \pm 0.53$ & $2.21^{\mathrm{b}} \pm 0.21$ & $1.41^{\mathrm{b}} \pm 0.10$ \\
RA2 & $88.8^{\mathrm{c}} \pm 1.22$ & $3.06^{\mathrm{c}} \pm 0.25$ & $1.77^{\mathrm{c}} \pm 0.07$ \\
RA3 & $114.8^{\mathrm{d}} \pm 1.13$ & $4.05^{\mathrm{d}} \pm 0.10$ & $2.15^{\mathrm{d}} \pm 0.09$ \\
LSD 5\% & 0.377 & 0.585 & 0.141 \\
Grand Mean & 11.38 & 4.41 & 9.09 \\
\hline
\end{tabular}

Means within the same column with different superscripts were significantly different at $(\mathrm{P} \leq 0.05)$, values are presented as means \pm standard error, $\mathrm{n}=3$, LSD - Least Significance Difference, GAF- Grain Amaranth Flour, RMF- Refined Maize Flour

Table 4: Sensory evaluation scores for 'ugali' from the blends

\begin{tabular}{lllllll}
\hline Samples & Appearance & Colour & Mouth feel & Texture & Taste & $\begin{array}{l}\text { Overall } \\
\text { Acceptability }\end{array}$ \\
\hline RMF & $8.17^{\mathrm{c}} \pm 0.14$ & $8.00^{\mathrm{c}} \pm 0.16$ & $7.63^{\mathrm{c}} \pm 0.18$ & $7.57^{\mathrm{c}} \pm 0.23$ & $7.80^{\mathrm{c}} \pm 0.19$ & $8.00^{\mathrm{c}} \pm 0.17$ \\
RA1 & $6.37^{\mathrm{b}} \pm 0.26$ & $5.93^{\mathrm{b}} \pm 0.3$ & $6.37^{\mathrm{b}} \pm 0.3$ & $6.20^{\mathrm{b}} \pm 0.3$ & $6.27^{\mathrm{b}} \pm 0.3$ & $6.27^{\mathrm{b}} \pm 0.29$ \\
& & 5 & 5 & 1 & 6 & \\
RA2 & $5.03^{\mathrm{a}} \pm 0.36$ & $4.97^{\mathrm{a}} \pm 0.35$ & $4.50^{\mathrm{a}} \pm 0.39$ & $4.73^{\mathrm{a}} \pm 0.39$ & $4.53^{\mathrm{a}} \pm 0.40$ & $4.93^{\mathrm{a}} \pm 0.38$ \\
RA3 & $4.40^{\mathrm{a}} \pm 0.33$ & $4.93^{\mathrm{a}} \pm 0.30$ & $4.30^{\mathrm{a}} \pm 0.44$ & $4.33^{\mathrm{a}} \pm 0.41$ & $4.20^{\mathrm{a}} \pm 0.43$ & $4.43^{\mathrm{a}} \pm 0.33$ \\
LSD 5\% & 0.771 & 0.825 & 0.945 & 0.962 & 0.959 & 0.804 \\
Grand & 6.08 & 5.98 & 5.69 & 5.79 & 5.75 & 6.00 \\
Mean & & & & & &
\end{tabular}

Means within the same column with different alphabetic superscripts were significantly different at $(\mathrm{p} \leq 0.05)$, values are presented as means \pm standard error, $n=30, \mathrm{LSD}-$ Least Significant Difference, GAF- Grain Amaranth Flour, RMF- Refined maize Flour 


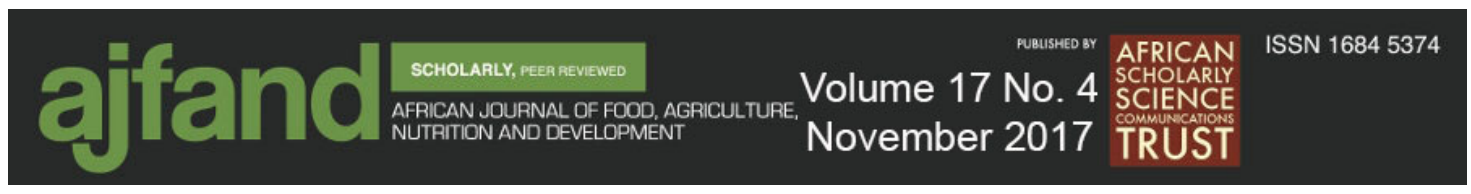

\section{REFERENCES}

1. O'Brien GK and ML Price Amaranth: Grain \& Vegetable Type. Echo Technical Note. ECHO. 17391 Durrance Rd, North Ft. Myers, FL 33917, USA, 1983.

2. Yarger L Amaranth: Grain and Vegetable Types. Echo Technical Note, Florida, 2008; $1-14$.

3. Kauffman CS and LE Weber Grain amaranth. Advances in new crops. Timber Press, Portland, 1990; 127-139.

4. Saunders RM and R Becker Amaranthus. In: Pomeranz Y (ed). Advances in Cereal Science and Technology. St. Paul, Minn, USA: American Association of Cereal Chemistry, 1983; 6: 6.

5. Njoki JW, Sila DN and AN Onyango Impact of Processing Techniques on Nutrient and Anti-Nutrient Content of Grain Amaranth (A. albus). Journal of Agriculture and Food Technology, 2014; 25: 10-17.

6. Kariuki SW, Sila DN and GM Kenji Nutritional Profile of Amaranth Grain Varieties Grown in Kenya. Journal of Agriculture and Food Technology, 2013; 17:19-25.

7. KDHS. Kenya Demographic and Health Survey. National Council for Population and Development, Central Bureau of Statistics and Ministry of Planning and National Development, Nairobi, Kenya 2008-2009.

8. Abuya BA, Ciera J and E Kimani-Murage Effect of Mother's Education on Child's Nutritional Status in the Slums of Nairobi. BMC Pediatr, 2012; 12: 80.

9. $\quad$ FAO. Nutrition country profile. Republic of Kenya. FAO, Rome, 2005; 3-4, 9$15,21-27,31-32$.

10. Hurrell RF, Reddy M, Dassenko SA and JD Cook Ferrous fumarate fortification of a chocolate drink powder. British Journal of Nutrition, 1991; 65: 271-283.

11. Macharia-Mutie CW, Van de Wiel AM, Moreno-Londono AM, Mwangi AM and ID Brouwer Sensory Acceptability and Factors Predicting the Consumption of Grain Amaranth in Kenya. Ecology of Food and Nutrition, 2011; 50: 375-392.

12. AOAC. Official methods of analysis of the Association of Official Analytical Chemists, I6 ${ }^{\text {th }}$ Edition. Volume II, Washington DC, 1995.

13. Pearson D The Chemical Analysis of Foods, $7^{\text {th }}$ edition. Churchill Livingstone, Edinburg, 1976. 
14. Hamaker BR, Kirleis LG, Butler AW, Axtell JD and ET Mertz Improving the in vitro protein digestibility of sorghum with reducing agents. Proceedings of the National Academy of Sciences of the United States of America, 1987; 84: 626628.

15. Batool SA, Rauf N, Tahir SS and R Kalsoom Microbial and Physico-chemical contamination in the wheat flour of the twin cities of Pakistan. Int J. Food Safety, 2012; 14: 75-82.

16. Rangana $\mathbf{S}$ Manual Analysis of fruits and vegetables production, $2^{\text {nd }}$ Edition, Tata McGraw Hill Co. Ltd., New Delhi, India, 1994.

17. Steel RGD and JH Torrie Principles and Procedures of Statistics, $2^{\text {nd }}$ Edition, New York: McGraw-Hill, 1980.

18. WFP. World Food Programme. Food Quality Control. www.wfp.org 2012. Last Accessed: 15 November 2012.

19. Bressani R and DR Colmenares Effect of Germination on the Chemical Composition and Nutritive Value of Amaranth Grain. Cereal Chemistry, 1990; 67: $155-84$.

20. Fandohn P, Hell K, Marasa WFO and MJ Wingfield Infection of Maize by Fusarium species and contamination with fumonisins in Africa. African Journal of Biotechnology, 2003; 2: 570-579.

21. Andraca I, Castillo $\mathbf{M}$ and $\mathbf{T}$ Walter Psychomotor development and behavior in iron-deficient anemic infants. Nutrition Revision, 1997; 55: 125-132.

22. Krebs NF, Westcott JE, Butler N, Robinson C, Bell M and KM Hambidge Meat as a first complementary food for breastfed infants: Feasibility and impact on zinc intake and status. Journal of Pediatric Gastroenterology and Nutrition, 2006; 42: 207-214.

23. Malomo O, Alamu EA and SO Oluwajoba Chemical Evaluation of Protein Quality of Sprouted Maize and Cowpea. International Journal of Nutrition and Food Sciences, 2013; 2 (5): 254-260.

24. Alonso R, Aguirre A and F Marzo Effect of extrusion and traditional processing methods on anti-nutrients and in vitro digestibility of proteins and starch in faba and kidney beans. Food Chem, 2000; 68: 159-165.

25. Correa AD, Jokl L and R Carlsson Chemical constituents, in vitro digestibility, and presence of anti-nutritional substances in amaranth grains. Arch. Latinoam. Nutr. 1986; 36: 319-326. 
26. Duodu KG, Nunes A, Delgadillo I, Parker ML, Mills ENC and PS Belton Effect of grain structure and cooking on sorghum and maize in vitro protein digestibility. J. Cereal Sci., 2002; 35:161-174.

27. ICMSF. Microorganisms in Foods: Microbial Ecology of Food Commodities. Blackie Academic and Professional, London, 1998; 6: 313-346.

28. Berghofer LK, Hocking AD, Miskelly D and E Jansson Microbiology of wheat and flour milling in Australia. Int J Food Microbiol, 2003; 85:137-49.

29. Bothast RJ, Anderson RA, Warner K and WF Kwole Effects of moisture and temperature on microbiological and sensory properties of wheat flour and corn meal during storage. Cereal Chemistry, 1981; 58: $309-311$. 